\title{
Setting up a Journal in OJS 3
}

På PKP/OJS egen hjemmeside findes en række videoer, der detaljeret viser dig, hvordan du sætter dit tidsskrift op I OJS 3. Du finder dem her:

http://pkpschool.sfu.ca/courses/setting-up-a-journal-in-ojs-3/

For at få adgang til videoerne skal du lade dig registrere - det er gratis og sker via linket 'Register' (1). Når du er blevet registreret, går du ind via - 'Take this Course' (2).

\section{PKP $\mid S C H O O L$}

Courses

\section{About}

1.

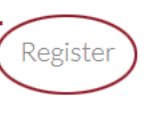

Members

Contact

\section{Setting up a Journal in OJS 3}

Hello and welcome! This course is designed for people who need to learn how to use the latest version of OJS quickly. Whether you are starting your own journal or are responsible for setting up a journal for someone else, you'll find all of the basics covered in this course, as well as pointers toward more advanced topics.

If you work through all of the modules in this course, you will be able to:

- Discover what is new in this latest version of OJS

- Perform the major tasks in configuring a new journal in OJS

- Analyze and solve common problems that may arise when using OJS

- Assist others with their use of OJS

- Know where to look for help when you don't know what to do

2.

Take this Course

Coursecontent

Modules
Expand All | Collapse All

Status

\section{Course Links}

Course Information

Course Fees \& Certification

Course Instructor

Course Authors

Course Journal

\section{Who's Online}

There are no users currently online

\section{Recent Comments}

- s1mon/3 on Unit 3: Review

○ juan beracaza on Unit 7: Navigation Menus

- juan beracaza on Module 15: Plugins - Custom Blocks

- Ramli on Course Evaluation

- Diego Cabral on Module 1: Course Introduction 
Du kan nu klikke på det modul, du ønsker at se.

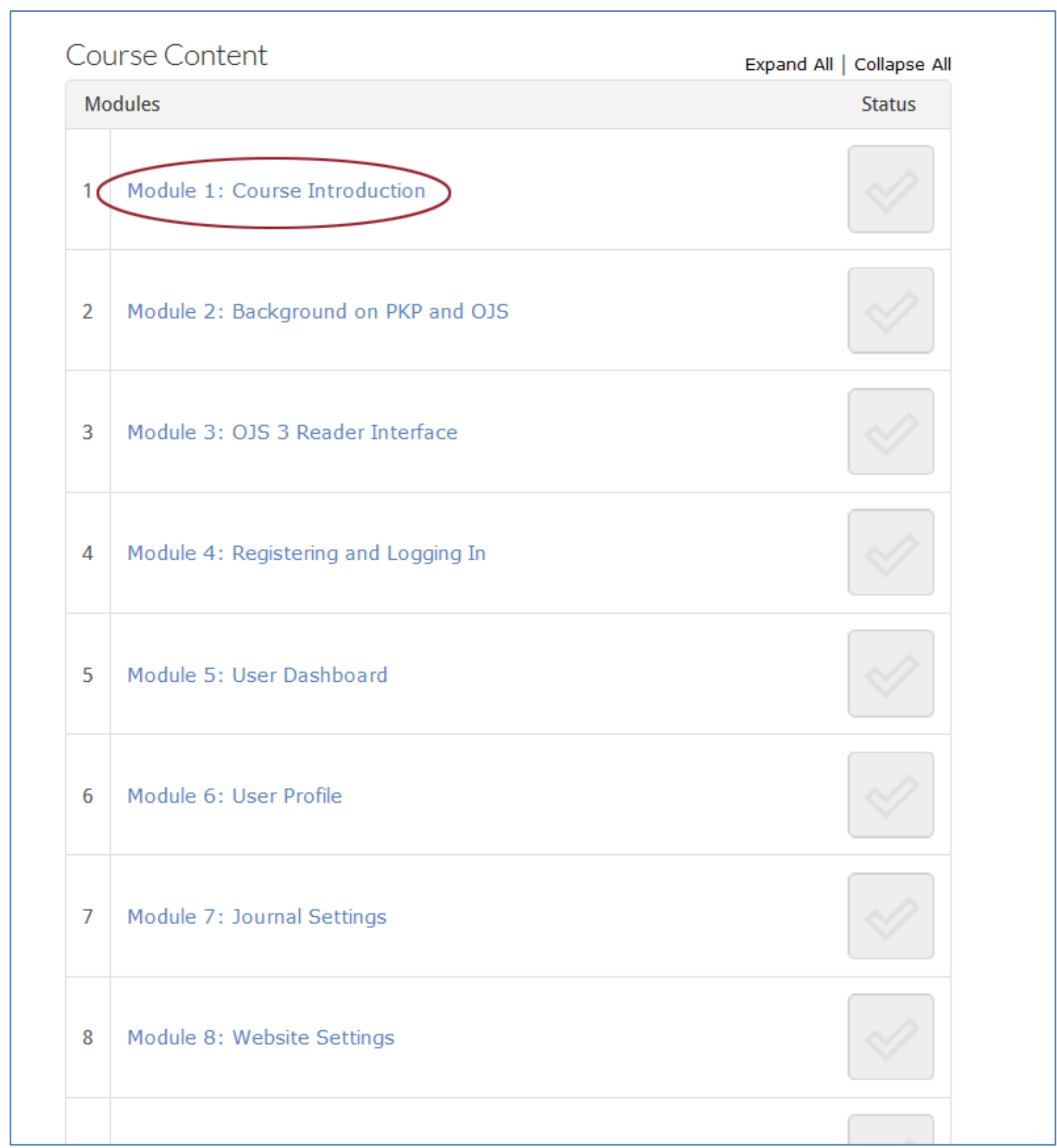

